\title{
New insights into late Devensian late glacial and early Holocene environmental change: two high-resolution case studies from SE England
}

Article

Accepted Version

Creative Commons: Attribution-Noncommercial-No Derivative Works 4.0

Simmonds, M. ORCID: https://orcid.org/0000-0001-7845-0392, Branch, N., Marshall, P., Hosfield, R. ORCID: https://orcid.org/0000-0001-6357-2805 and Black, S. ORCID: https://orcid.org/0000-0003-1396-4821 (2021) New insights into late Devensian late glacial and early Holocene environmental change: two high-resolution case studies from SE England. Review of Palaeobotany and Palynology, 287. 104364. ISSN 0034-6667 doi:

https://doi.org/10.1016/j.revpalbo.2020.104364 Available at https://centaur.reading.ac.uk/95048/

It is advisable to refer to the publisher's version if you intend to cite from the work. See Guidance on citing.

To link to this article DOI: http://dx.doi.org/10.1016/j.revpalbo.2020.104364

Publisher: Elsevier 
copyright holders. Terms and conditions for use of this material are defined in the End User Agreement.

\section{www.reading.ac.uk/centaur}

\section{CentAUR}

Central Archive at the University of Reading

Reading's research outputs online 


\section{New insights into Late Devensian Lateglacial and early}

2 Holocene environmental change: two high-resolution case

3 studies from SE England

4 Michael Simmonds $^{1 凶}$, Nicholas Branch ${ }^{1}$, Peter Marshall ${ }^{2}$, Robert

5 Hosfield ${ }^{1}$, and Stuart Black ${ }^{1}$

$6 \quad{ }^{1}$ Department of Geography and Environmental Science, School of Archaeology,

7 Geography and Environmental Science, Whiteknights, University of Reading, UK.

$8{ }^{2}$ Historic England, Cannon Bridge House, 25 Dowgate Hill, London, UK.

$9 \square$ Corresponding author: m.j.simmonds@reading.ac.uk

10

11 Keywords:

12 Lowland wetland; Vegetation dynamics; Palaeoecology; Peat bog; Palynology; Stable 13 isotopes; 


\section{Introduction}

Despite a number of palaeoenvironmental records across south-east (SE) England, they are unevenly distributed and concentrated in coastal regions, especially the Kent and East Sussex coast (Kerney et al., 1980; Thorley, 1981; Waller, 1993; Waller and Marlow, 1994; Preece and Bridgland, 1998; Waller et al., 1999; Waller and Hamilton, 2000; Waller and Long, 2010), and the Solent (Scaife, 1980, 1987) (Figure 1). There is also a considerable bias towards records from floodplain locations, particularly along the lower reaches of the River Thames (Gibbard and Hall, 1982; Branch and Lowe, 1994; Wilkinson et al., 2000; Corcoran et al., 2011; Batchelor et al., 2012; Branch et al., 2012; Batchelor et al., 2014; Batchelor et al., 2015; Batchelor et al., 2019) and the Upper River Thames and River Kennett (Healy et al., 1992; Lewis et al., 1992; Parker and Robinson, 2003; Chisham, 2004). There are only a small number of sites from inland, lowland wetland locations that have provided well-dated palaeoenvironmental records, including Spartum Fen (Parker, 2000), Bagshot (Groves, 2008), Conford (Groves et al., 2012) and Elstead Bog (Farr, 2008), although they do not all provide a continuous Lateglacial and early Holocene sequence.

\section{Current understanding from the limited available data suggests that four main} biostratigraphic zones exist (Branch and Green, 2004; Groves, 2008; Groves et al., 2012) during the Lateglacial and early Holocene (Table 1). Pre 11,500 cal. BP, there was open scrubby tundra style vegetation comprising Juniperus type, Betula and Salix woodland that often continued into the early Holocene. From 11,500-11,200/10,500cal. BP Pinus became dominant in dryland areas alongside Betula. On the wetland edge Salix continued to be the dominant taxon, alongside Cyperaceae. Between 10,200-8900 cal. BP mixed deciduous woodland of Quercus, Betula, Corylus and Ulmus developed in previously Pinus dominated areas; Salix dominated the wetland edge. From 8900-7000 cal. BP mixed deciduous woodland dominated drier areas, with the emergence of Tilia, the loss of Betula, with Alnuscarr woodland formation in the wetter areas. 
Table 1. Palaeoenvironmental sites in SE England with evidence for one or more of the biostratigraphic zones

This observed framework requires testing and refinement however due to the uneven distribution and paucity of sites. Here we present a comparison and discussion of the pollenstratigraphical and sedimentary results from two new unique Lateglacial and early Holocene sequences in SE England: Langshot Bog and Elstead Bog B, which are integrated with data from Elstead Bog (Carpenter and Woodcock, 1981; Farr, 2008), other sites in SE England (Figure 1) and more widely in Britain and NW Europe. These two sites develop our knowledge on the nature of vegetation succession, and temporal variability in vegetation dynamics, during the Lateglacial and early Holocene, and provide an opportunity to contribute to current debates about vegetation change as a response to known periods of abrupt climate change and human activity (Barton and Roberts, 2004; Barton, 2009; Rasmussen et al., 2014).

Figure 1. Location map of the two study sites and other key palaeoenvironmental sites in SE England.

\subsection{The sites: Langshot Bog and Elstead Bog B}

Langshot Bog (Figure 1) is located on the southern side of Chobham Common $\left(51^{\circ} 21^{\prime}\right.$ 43.0" $\mathrm{N} 00^{\circ} 35^{\prime} 53.2^{\prime \prime} \mathrm{W}$; elevation: c. $30 \mathrm{~m}$ a.s.I.) and is a $0.12 \mathrm{~km}^{2}$ area of superficial peat, situated on the Bracklesham Group. Chobham Common is a large expanse of heathland in Surrey and is the largest National Nature Reserve in SE England, managed by the Surrey Wildlife Trust. On Langshot Bog, species of Sphagnum occupy the bog surface (Sphagnum compactum, S. papillosum, S. recurvum and S. palustre) alongside other plants such as Drosera rotundifolia, Narthecium ossifragum, Eriophorum angustifolium, Osmunda regalis, and Gentiana pneumonanthe. Much of the bog surface is wooded, with Betula pubescens and Alnus glutinosa the dominant tree taxa. The modern-day vegetation across the Common 
itself is dominated by Calluna vulgaris, Erica cinerea, and Ulex minor (plant nomenclature follows the flora of the British Isles Stace (2010)).

Figure 2. The location of Langshot Bog highlighting the coring transects and sampling location

Elstead Bog B (Figure 1) is a $\sim 0.003 \mathrm{~km}^{2}$ peat basin located within pine woodland in Surrey (51 $11^{\circ} 18.3^{\prime \prime} \mathrm{N} 00^{\circ} 43^{\prime} 00.6 " \mathrm{~W}$; elevation: c. 52m a.s.I.), situated on gently downward sloping ground towards the Wey Valley to the north, with the ground rising steeply to the south. The site is nearby to the previously investigated Elstead Bog (Seagrief and Godwin, 1960; Carpenter and Woodcock, 1981; Farr, 2008). The underlying geology is well sorted Folkestone Bed sands of the Lower Greensand (Carpenter and Woodcock, 1981). Soils are thin and podzolised, immediately resting on the Lower Greensand. Bog surface vegetation is dominated by Molinia caerulea and Sphagnum (Sphagnum compactum, S. papillosum, $S$. recurvum, and S. palustre), with Betula pubescens on stable areas. Around the bog margins, Calluna vulgaris and Erica tetralix prevail, with Pinus sylvestris in the wider woodland.

Figure 3. The location of Elstead Bog B showing the coring transects and the site of Elstead Bog

\section{Methods}

A stratigraphic coring survey was used to understand the size and shape of the two sites. At Langshot Bog, two transects, running east-west, and north-south, were sampled at $20 \mathrm{~m}$ intervals, which resulted in 9 cores running west to east, and 13 cores running south to north (Figure 2). Cores were extracted until the corer hit sandy Bracklesham group sediments, identified within sediments in the base of each core, or observed whilst coring. At Elstead Bog B an east to west transect of 9 boreholes ( 5 metre spacing) and a north to south transect of 11 boreholes (10 metre spacing) cored down to the parent material, the Sandgate Formation (Figure 3). The deepest surveyed points were used as master coring locations. All 
cores were collected using a Russian corer (or D-section corer), a hand coring device that cuts an undisturbed $500 \mathrm{~mm} \times 50 \mathrm{~mm}$ section of core, a method widely used in palaeoenvironmental sampling because of the high quality of extracted sample (Moore et al., 1991) and the speed and ease of operation (Jowsey, 1966). At each site, two boreholes, situated no more than $30 \mathrm{~cm}$ apart, allowed for each core section to have an overlap of $10 \mathrm{~cm}$, and meant there was no disturbance of lower samples. Cores for further analysis were wrapped in rigid plastic downpipe and kept in cold storage $\left(<4^{\circ} \mathrm{C}\right)$ at the University of Reading. Core stratigraphy was described by reference to the Troels-Smith classification scheme (Troels-Smith, 1955). Colour was noted from a Munsell Colour Chart and determination of organic content by loss-on-ignition (Bengtsson and Enell, 1986).

The alkali-soluble ('humic acid') and alkali- and acid-insoluble ('humin') fractions of bulk peat samples taken from above and below lithostratigraphic and biostratigraphic unit boundaries were dated by Accelerator Mass Spectrometry (AMS) at the Scottish Universities Environmental Research Centre (SUERC) and ${ }^{14} \mathrm{CHRONO}$ centre, Queen's University Belfast. The samples dated at Queen's University Belfast were pre-treated and measured following the methods described in Reimer et al. (2015). Despite six attempts trying both hydrogen reduction (four times), and zinc reduction (twice) the humin sample (UBA-26775) from Langshot Bog $(137-138 \mathrm{~cm})$ failed to graphitise. Usually a sample fails to graphitise due to a higher than normal sulphur content and thus the laboratory increased the amount of silver present in the combustion tube but unfortunately this failed. Subsequent analysis of the sediment from this portion of the core identified very high concentrations of pyrite $\left(\mathrm{FeS}_{2}\right)$. Pyrite releases sulphur oxides when combusted which can hamper the reduction of carbon dioxide to graphite (Proske et al., 2015).

The samples dated at SUERC were pre-treated using methods outlined in Stenhouse and Baxter (1981), combusted following Vandeputte et al. (1996), graphitised as described by Slota et al. (1987), and measured by AMS (Freeman et al., 2010). Internal quality assurance 
procedures and international inter-comparisons (Scott, 2003; Scott et al., 2010) indicate no laboratory offsets and validate the measurement precision quoted. Details of the dated samples, radiocarbon ages, and associated stable isotopic measurements are provided in Tables 2-3. The radiocarbon results are conventional radiocarbon ages (Stuiver and Polach, 1977). A weighted mean (Ward and Wilson, 1978) has been taken as providing the best estimate for the age of formation of the dated horizons (Tables 2-3) before inclusion in the age-depth model. The age-depth model (Figure 5) has been constructed using the program OxCal v4.2 (Bronk Ramsey, 2009; Bronk Ramsey and Lee, 2013) and the atmospheric calibration curve for the northern hemisphere published by Reimer et al. (2013). The P_Sequence Poisson process model (Bronk Ramsey, 2008) employs a variable $k$ parameter (Bronk Ramsey and Lee, 2013) with the overall age-depth model defined as P_Sequence $(1,1, \cup(-2,2))$, with $k_{0}$ (the base $k$ parameter) $=1 \mathrm{~cm}^{-1}$, the interpolation rate $=1 \mathrm{~cm}^{-1}$ (output from the model given every $1 \mathrm{~cm}$ ), and variability in $k$ allowed between a factor of $10^{-2}$ and $10^{2}$.

Sub-samples for pollen analysis were derived from a $1 \mathrm{~cm}^{3}$ volumetric sampler (Bennett and Willis, 2002). At Langshot Bog and Elstead Bog B, sampling at an interval of $2 \mathrm{~cm}$ provided a very high-resolution vegetation record in respect to core length. At Langshot Bog this equated to an average time-depth resolution of 50 years per sample ( 25 years $\left.\mathrm{cm}^{-1}\right)$. Samples were prepared for pollen analysis with the addition of the exotic pollen marker keys (Moore et al., 1991; Reille, 1995), and pollen nomenclature follows Moore (et al. 1991). Pollen percentage values were calculated in Tilia version 1.7.16 (Grimm, 2011) based upon a pollen sum of $\sim 300$ total land pollen (TLP). This count excluded aquatic species and spores; subsequently calculated as a percentage of their totals + TLP. Microscopic charred 
particles were recorded quantitatively using a modified method from Robinson (1984) where MCP were counted relative to the trees, shrub and herb pollen count at the same time as pollen grains (Simmons and Innes, 1996; Innes et al., 2004; Innes et al., 2010). Different size classes for the charcoal were not implemented, due to the potential for fragmentation during the pollen preparation process, potentially artificially increasing charcoal counts in small size classes (Innes et al., 2004; Innes et al., 2010). Tilia.graph (Grimm, 2011) was used to draw pollen diagrams, and constrained incremental sum of squares clustering (CONISS) was used to help divide the percentage pollen diagram into a number of local pollen assemblage zones (Grimm, 1987). Pollen influx values were calculated for the Langshot Bog sequence, based upon the pollen concentration (grains $\mathrm{cm}^{-3}$ ) and deposition time $\left(\right.$ years $\mathrm{cm}^{-1}$ ). Values are expressed as a pollen deposition rate (grains $\mathrm{cm}^{-2} \mathrm{year}^{-1}$ ) and represent the number of grains incorporated into the unit area of sediment each year.

Samples for stable isotope analysis $\left(\delta^{18} \mathrm{O}\right.$ and $\left.\delta^{2} \mathrm{H}\right)$ were extracted at the same locations as the pollen samples from the Langshot Bog sequence. Individual culm and leaf macrofossils of Carex were extracted from the core and checked under a Leica S6D zoom-stereo microscope at $\times 10$ magnification to ensure homogeneity throughout the sequence. These leaf macrofossil samples were dried and weighed into silver capsules and analysed for $\delta^{2} \mathrm{H}$ and $\delta^{18} \mathrm{O}$ on a Thermo-Fisher Delta $\mathrm{V}$ Advantage IRMS fitted with a TC Flash EA at the University of Reading in the Chemical Analytical Facility. The IRMS data was corrected for both drift and stretch corrections using international standards following blank corrections (Eley et al., 2014). Precision on independent standards run alongside the unknown samples was $\pm 0.15 \%$ for $\delta^{18} \mathrm{O}$ and $1.58 \%$ or for $\delta^{2} \mathrm{H}$.

\section{Results}

\subsection{Langshot Bog: Lithostratigraphy, chronology and stable isotopes}


181 The transect survey at Langshot Bog indicates that the unconsolidated sediments running east-west have a depth of $150-210 \mathrm{~cm}$. The north-south sequence has an undulating profile of shallow and deeper cores up to $242 \mathrm{~cm}$ in depth. The deepest location on this north-south transect $\left(51^{\circ} 21^{\prime} 43.0^{\prime \prime} \mathrm{N} 00^{\circ} 35^{\prime} 53.2^{\prime \prime} \mathrm{W}\right)$ was chosen as the master core sequence for Langshot Bog (Figure 4).

Figure 4. Stratigraphic results from the two Langshot Bog transects.

The sediments at the base of the sequence (unit 1) are sand-rich, representing the local Bracklesham geology at the site, with low organic matter values ( 40\%). Organic sediment accumulation (unit 2) started prior to $12,570-11,910$ cal. BP (95\% probability ${ }^{1}, L B 1 / 2$, Figure 5) and lake sediment has been observed at the base of other sequences from the site, immediately overlying the Bracklesham Beds. Palaeo-hydrological studies often interpret shifts in sedimentary organic matter $\delta^{2} \mathrm{H}$ and $\delta^{18} \mathrm{O}$ values in terms of palaeo-precipitation (Pagani et al., 2006; Schefuß et al., 2011; Magill et al., 2013). This relies on the assumption that any temporal change in the isotopic composition of plant $\delta^{2} \mathrm{H}$ and $\delta^{18} \mathrm{O}$ values of the sedimentary archives reflects shifts in the isotopic composition of source water through time (Leider et al., 2013). The trends observed within the Langshot Bog isotopic data appear to show that the $\delta^{18} \mathrm{O}$ and $\delta^{2} \mathrm{H}$ records are not synchronous and are decoupled, matching trends observed previously in other stable-isotope studies (Eley et al., 2014) where the $\delta^{2} \mathrm{H}$ data reflects the plant community, whilst a climatic signal is provided by the $\delta^{18} \mathrm{O}$ data. During this period of peat formation, it is likely that small pools were present across the site occupying natural hollows in an undulating sandy land surface. A short period of decreasing evaporation (as indicated by depleted $\delta^{18} \mathrm{O}$ values) may indicate slightly drier conditions to

\footnotetext{
${ }^{11}$ Highest Posterior Density intervals which describe the posterior distributions derived from age-depth modelling are given in italics (and quoted at 95\% probability) to distinguish them from simple calibrated dates that are given in plain text (and are quoted at $2 \sigma$ ).
} 
allow peat formation to begin, although the low humification of the peat in this unit suggests that the bog surface was still relatively wet.

Peat formation continued in unit 3 until 12,010-11,640 cal. BP (95\% probability, LB2/3, Figure 5). Shallow bog pools and wet peaty conditions were present at this point. The wet bog surface conditions indicated by the vegetation community correlate with the isotope records through this period (Figure 6), which indicate a marked shift to wetter conditions (depleted $\delta^{2} H$ ) with increased evaporation (enhanced $\delta^{18} \mathrm{O}$ ). A small influx of sands and silts in units 2 and 3 are thought to represent in-washing from the higher elevated slopes around the edge of the basin, potentially caused by strong storm events, corresponding with wetter conditions or a loss of surface vegetation. An increase of trees on the surface of the bog (unit 4) from 12,010-11,640 cal. BP (95\% probability, LB2/3, Figure 5), suggested from wood peat (unidentified) found within this unit, correlates with a distinctive shift in the $\delta^{18} \mathrm{O}$ values indicating lower levels of evaporation. This may be a response to an early Holocene drying out of the surface of the bog. A period of relatively stable peat accumulation then continues from the onset of the Holocene until 9790-9470 cal. BP (95\% probability, $96 \mathrm{~cm}$, Figure 5). During this time, localized changes in wetness are highlighted within the isotope data, which shows a period of instability, with overall trends indicating increased evaporation and slightly wetter conditions as this unit progresses. Two events within this period of instability stand out, with decreased evaporation at 11,350-10,715 cal. BP (95\% probability, $162 \mathrm{~cm}$, Figure 5) and at 10,850-10,520 cal. BP (95\% probability, $140 \mathrm{~cm}$, Figure 5), although any response from the vegetation ( $\delta^{2} \mathrm{H}$ values) appears muted. An increase in humification in unit 5, aligned with an increase in Substantia humosa, indicates a further drying out of the bog surface from $9790-9470 \mathrm{cal}$. BP (95\% probability, $96 \mathrm{~cm}$, Figure 5) to $8430-8350 \mathrm{cal}$. $B P\left(95 \%\right.$ probability, wm65, Figure 5). The $\delta^{2} \mathrm{H}$ record identifies a broad drying trend, alongside a reduced amount of evaporation suggested by the $\delta^{18} \mathrm{O}$ profile. An increase in mineral influx and decline in organic matter is attributed to an increase in burning events 
(Figure 6), causing increased runoff and in-washing of mineral matter into the basin. A hiatus in the sedimentary record is identified between units 5 and 7 , thought to have occurred from $8430-8350$ cal. BP (95\% probability, wm65, Figure 5) (unit 6), where there is a large influx of mineral material.

Figure 5. Bayesian age-depth model of the chronology of the sediment sequence at Langshot Bog (P_Sequence model ( $k=0.01-100)$; Bronk Ramsey 2008). For each of the radiocarbon dates two distributions have been plotted: one in outline, which is the result of simple calibration, and a solid one, which is based on the chronological model used. Figures in brackets after the sample numbers are the individual indices of agreement which provide an indication of the consistency of the radiocarbon dates with the prior information included in the model (Bronk Ramsey, 1995).

Table 2. Radiocarbon dates from Langshot Bog. Replicate measurements have been tested for statistical consistency and combined by taking a weighted mean before calibration as described by Ward \& Wilson (1978; $\left.T^{\prime}(5 \%)=3.8, v=1\right)$.

Figure 6. Composite stratigraphy, isotopic results, and age-depth model for Langshot Bog.

\subsection{Langshot Bog: Pollen Stratigraphy}

The Lateglacial at Langshot Bog (Figure 7: Local Pollen Zone (LB-1)) shows vegetation indicative of a cold, tundra-style landscape of shrubland and short turf grassland with Ericaceae and Cyperaceae. It was species-poor with natural burning events and characterised by a very sparse scrubby scatter of Betula and Juniperus type. These species are cold tolerant, which is important as this zone can be chronologically correlated with the start of the Loch Lomond Stadial (Walker et al., 1994), dating from 13,210-12,430 cal. BP (95\% probability, $241 \mathrm{~cm}$, Figure 8) to $12,570-11,910$ cal. BP (95\% probability, LB1/2, Figure 8). Ericaceae is present due to its ability to regenerate after fires (Averis, 2013), which based on the charcoal record would have been regular occurrences throughout this period. Regular fires have been observed at other sites in the UK and NW Europe during the last Glacial period (Kolstrup, 1992; Edwards et al., 2000) although understanding their onset has been difficult, a point explored further in the discussion. Ericaceae, and Betula, are resistant to wind exposure and are likely to indicate the presence of small heathland patches as 
observed elsewhere in the UK (Bennett, 1983; Walker et al., 2003). Juniperus type colonises unstable ground surfaces and can survive in poor soils with low nutrient content (Averis, 2013). The low percentages (predominantly <5\%) suggest that dwarf Juniperus type was present, and alongside Artemisia indicate year-round temperatures would have been relatively cold (Kolstrup, 1980). Pinus might have been present on both drier and wetter soils but the low influx values (Figure 9) may also indicate long distance pollen transport.

Figure 7. Langshot Bog, Chobham Common: pollen percentage diagram.

LB-2 is a similar tundra-style vegetation mosaic, and the dating has enabled correlation with the mid-late Loch Lomond Stadial: 12,570-11,910 cal. BP (95\% probability, LB1/2, Figure 8) to $12,010-11,640$ cal. BP (95\% probability, LB2/3, Figure 8). A consistent influx of Salix suggests it is underrepresented in the pollen percentage data and that it would have formed a component of the local woodland cover, around the wetland margins. The relatively open landscape present at this time suggests that Salix and Betula are likely to have been dwarf species, with both Betula nana and Salix herbacea identified in British Lateglacial contexts (Blackburn, 1952; Birks, 1965; Beerling, 1998). There was no attempt to do size frequency measurements on the Betula (Birks, 1968), as no distinct difference was observed and therefore, we cannot be definitive about the Betula species present during this time. Juniperus type increases, potentially due to a reduction in burning, and there is a small expansion of various herbaceous taxa, including Filipendula and Poaceae, which could quickly colonise bare ground on the wetland margin along with Artemisia. An increase in the pollen influx of Equisetum, Sphagnum and Typha latifolia in this zone represents the growth of these species in small pools or damp areas of this undulating landscape.

The end of the stadial is indicated by a rise in Betula from 12,010-11,640 cal. BP (95\% probability, LB2/3, Figure 8), and a decline in Juniperus type and Cyperaceae (LB-3). A transition from Betula-dominated to Pinus/Betula woodland occurs during the very early 
Holocene at 11,810-11,150 cal. BP (95\% probability, LB3/4, Figure 8), and represented a period of drier bog surface conditions as Sphagnum declines (LB-4). At this time, woodland began to expand in the local area, indicated by an increase in the total tree pollen sum and tree pollen influx data (Figure 13). Although Pinus appears dominant, the influx data (Figure 9) indicates Betula did not decline as rapidly as the percentage data implies. This mixed Pinus/Betula woodland lasts until 10,440-10,230 cal. BP (95\% probability, LB4/5, Figure 8) and was dense, due to a lack of an herbaceous understory, with woodland also present on drier parts of the bog itself. A small increase in Corylus across LB-4 indicates continued warming of the climate in the early Holocene (Birks, 1989) as Corylus prefers warmer conditions, extended growth seasons and a less variable climate (Tallantire, 2002). However, the very low pollen influx values indicate these are either scattered trees rather than Corylus woodland or indicate long-distance transport of Corylus pollen.

Figure 8. Probability distributions of key events from Langshot Bog (derived from the agedepth model described in Figure 5) and their relationship to key climatic events.

As temperatures warm during the early Holocene (Davis et al., 2003), thermophilous species are observed in abundance in LB-5 from 10,440-10,230 cal. BP (95\% probability, LB4/5, Figure 8). Corylus rapidly expands at this point, along with the arrival of Ulmus, potentially indicating a reduction in precipitation (Hall, 1978). A rapid decline in the influx of Pinus pollen indicates an inability to compete with newly arriving species (Birks, 1989). An increase in microscopic charcoal could be evidence for human induced woodland clearance, potentially for attracting animals to the water source, although drier conditions would also have led to an increased chance of natural burning events. A sustained increase in Calluna vulgaris suggests small heathland areas may have been present in the landscape. Although present in small amounts in LB-5, Quercus expands slightly later than the other thermophilous taxa, at the start of LB-6, from 9540-9480 cal. BP (95\% probability, wm95; Figure 8). Additionally during LB-6, Corylus started to form the understorey vegetation (Godwin, 1975) as the 
canopy of the deciduous woodland grew denser. An increase in humification, aligned with an increase in Substantia humosa, indicates a drying of the bog surface, supported by enhanced $\delta^{18} \mathrm{O}$ values representing increased evaporation. An increase in Poaceae as well as the presence of other herbaceous (Plantago media/major) and shrub (Ericaceae, Calluna vulgaris) species suggests the continued development of clearings within the woodland, although it is not known whether these clearings were permanent or intermittent in nature. Burning events increased and could be due to either anthropogenic or natural causes, although the increase in Poaceae and relative stability of many arboreal species may indicate selective burning of woodland species to create cleared areas, likely helped by, or focused around the fall of senescent trees. The mixed open deciduous woodland remains established until 8430-8350 cal. BP (95\% probability, wm65, Figure 8$)$. The subsequent hiatus means timings past this point are uncertain and zones LB-7, 8 , and 9 are not discussed further.

Figure 9. Langshot Bog, Chobham Common: selected pollen taxa influx.

\subsection{Elstead Bog B: Lithostratigraphy and chronology}

Two transects helped understand the morphological characteristics of the basin at Elstead Bog B and a $221 \mathrm{~cm}$ core was extracted at their crossover point $\left(51^{\circ} 10^{\prime} 18.3^{\prime \prime} \mathrm{N} 00^{\circ} 43^{\prime}\right.$ 00.6"W); which is the deepest part of the basin (Figure 10). The core consists of 32 separate lithological units (Figure 11). Three radiocarbon determinations were obtained from the Elstead Bog B core (Figure 11) with the samples taken from locations in the core where LOI indicated high organic matter content (>10\%), however, no age-depth model could be created for the sequence (Simmonds, 2017, 261-262). An 8410-8915 year interval (95\% probability) between the dates at $168-169 \mathrm{~cm}$ and $138-139 \mathrm{~cm}$ suggests the existence of a hiatus in the sequence, tentatively placed at $158 \mathrm{~cm}$ due to a large reduction in organic matter and corresponding lithological shift at this depth. The age of the sample at 168$169 \mathrm{~cm}, 11,820-11,400 \mathrm{cal}$. BP (WM-168, 20), indicates that there are early Holocene, and 
potentially Lateglacial, deposits surviving. The presence of the hiatus at $158 \mathrm{~cm}$ means discussion will be focused on material below this level. Due to the low organic matter content of the material at the base of the sequence no further samples were submitted for radiocarbon dating.

Figure 10. Stratigraphic results from the two transects at Elstead Bog B.

Table 3. Radiocarbon dates from Elstead Bog B. Replicate measurements have been tested for statistical consistency and combined by taking a weighted mean before calibration as described by Ward \& Wilson (1978; $\left.T^{\prime}(5 \%)=3.8, v=1\right)$, except for those in bold that are not consistent at the $5 \%$ level.

The basal lithostratigraphic units (1-4) of fine and coarse sands indicate the bedrock geology of the Lower Greensand (Gallois, 1965). Organic matter and organic lake sediment (units 5 and 7) are interspersed with sand (units 6, 8, and 9), potentially at a time when there was a slight destabilisation of the slopes on the edges of the bog, either through increased storminess or changes in vegetation cover (Orme et al., 2016). A period of lake sedimentation is observed (units 10-13) and continued until the transition from the Lateglacial to the early Holocene. High values of Potamogeton subgenus Potamogeton type at this time suggest a small pool of still or slow flowing water (Fitter, 1987). A gradual shift from Potamogeton subgenus Potamogeton type to Myriophyllum alterniflorium suggests a slight shallowing and infilling of this pool towards the onset of the Holocene (Fitter, 1987). The beginning of the Holocene (units 14-18) is characterised by an increase in herbaceous peat growth. Sparganium would have grown in the shallow water margins of the water body (Cook, 1961), and its presence indicates a reduction in the size of the pool and the gradual development of peat encroaching from the margins.

Figure 11. Elstead Bog B: stratigraphy, organic matter, and radiocarbon dates. 
The Lateglacial vegetation record from Elstead Bog B (EBB-1) indicates a cold, open landscape (Figure 12). Salix and Alnus would have been present on moist to wet ground with Pinus and Betula present across a range of soil types. As suggested at Langshot Bog, Salix and Betula may have been dwarf species. Ericaceae would have been present on moist slopes, present here due to its ability to regenerate after fire events. Herbaceous taxa Ranunculus type, Poaceae and Artemisia would have been scattered across disturbed parts of the landscape (Clapham et al., 1987; Averis, 2013). During EBB-2, high values of Potamogeton subgenus Potamogeton type suggest a body of still or slow flowing water (Fitter, 1987) with Cyperaceae on the edges of this water body (Chapin and Chapin, 1980). The dry-ground flora remains relatively consistent with the most significant development being the arrival of Juniperus type, suggesting lower year-round temperatures. The radiocarbon chronology suggests that EBB-1 and EBB-2 may be correlated to the onset of the Loch Lomond Stadial, with both a lowering of temperatures and increased precipitation (Lowe and Walker, 2015). In EBB-3, the relatively high Juniperus type values suggest that to ameliorate pioneering taxa such as Betula and Pinus would have formed woodland the climate was still cold (Rawat and Everson, 2012), and the landscape continued to be relatively species poor. Calluna vulgaris represents a scrubby heathland element and has previously been identified in Late Devensian Lateglacial records (Godwin, 1975). High levels of Poaceae, Cyperaceae and Rumex undiff. suggest that disturbed open ground is present (Pennington et al., 1977), with a shift from Potamogeton subgenus Potamogeton type to Myriophyllum alterniflorium indicative of shallowing of the water body because of warming at the end of the Lateglacial.

A rapid increase in Betula is observed at the transition from the Lateglacial to the Holocene at 11,820-11,400 cal. BP (WM-168; 2 $)$ ) at Elstead Bog B (Figure 12). As the climate began (Bennett, 1983; Birks, 1989). Salix would have been present in wetter areas (Averis, 2013), and Equisetum and Sparganium erectum would also have grown in damp shallow water 
margins of the lake (Cook, 1961; Clapham et al., 1987). Their presence indicates a reduction in the size of the water body and the gradual encroachment of peat. The decline in Poaceae, Cyperaceae and other herbaceous taxa suggests that the woodland was closed with little or no understorey (Godwin, 1975).

Figure 12. Elstead Bog B: Pollen percentage diagram.

\section{Discussion}

Contextualising these two new palaeoenvironmental records in their contemporary timescape (Figure 13) helps develop our understanding of sedimentary history, vegetation succession, climatic change and human activity during the Lateglacial and early Holocene in both SE England and more widely across NW Europe.

Both Langshot Bog and Elstead Bog B formed as small pools within hollows in the naturally undulating sandy Bracklesham Beds and Lower Greensand, respectively. A lack of ramparts suggest these sites were not formed from the collapse of cryogenic mounds (pingos), as thought to be the case at Elstead Bog (Carpenter and Woodcock, 1981). Unusually, the radiocarbon dated sedimentary records indicate that the onset of organic sedimentation at both sites occurred during the Late Devensian Lateglacial and can be chronologically correlated with the Loch Lomond Stadial. This indicates that there was sufficient vegetation and low levels of landscape erosion permitting organic sedimentation. Importantly, this is in contrast to records from the north and west of Britain where sediments are often highly mineral rich, with no organic component, such as at Mill House 1, The Flasks 69 (Innes et al., 2009), Whitrig Bog (Mayle et al., 1997), Llyn Gwernan (Lowe and Lowe, 1989), Llanilid (Walker et al., 2003) and Sluggan Bog (Lowe et al., 2004). At other sites in SE England, organic sedimentation started prior to the Loch Lomond Stadial, during the Windemere Interstadial, including those at Holywell Coombe (Preece and Bridgland, 1999). It is unclear why earlier sediments are not present at Langshot Bog and Elstead Bog B, but it may be due 
to the survey and sampling strategy, drier climatic conditions preventing sediment accumulation, the absence of impeded drainage (forming a 'closed' basin) until later in the Lateglacial or sediment erosion by fluvial or aeolian processes. These processes could have been exacerbated by climatic fluctuations in the Lateglacial Interstadial, as observed at Holywell Coombe (Preece and Bridgland, 1999). Organic sediment deposition during the Stadial at Langshot Bog and Elstead Bog B probably occurred due to a combination of factors, reflecting both regional climatic and geological influences. A warmer climate during the Loch Lomond Stadial in SE England is indicated by molluscan records from Holywell Coombe (Kent) with mean summer temperatures of $\sim 16^{\circ} \mathrm{C}$ (Rousseau et al., 1998) compared to mean summer temperatures of $\sim 10-11^{\circ} \mathrm{C}$ at Llanilid (Wales) (Walker et al., 2003), $6-7.5^{\circ} \mathrm{C}$ at Hawes Water (northern England) (Marshall et al., 2002) and $\sim 7.5-9^{\circ} \mathrm{C}$ at Whitrig Bog (Scotland) (Brooks and Birks, 2000), based upon coleopteran and chironomid data. Warmer southern temperatures may have meant a muted response to the reversal to colder climatic conditions, which would mean that erosive processes would not take hold as quickly or as significantly as it did in other areas, where species-poor slopes brought unweathered minerogenic material into the basins (Walker et al., 2003).

\section{Organic sedimentation during the Loch Lomond Stadial permits a reconstruction of the} vegetation history during this period, which is unusual in SE England. Significantly, similar successional trends between Elstead Bog B and Langshot Bog, sites over 20km apart, suggest these basins provide a coherent regional signal of vegetation history. The two records indicate that herbaceous taxa (Poaceae, Artemisia, Caryophyllaceae) would have been present across much of the open ground with Cyperaceae, Sphagnum, Equisetum and Typha latifolia indicating reed and sedge swamp and small pools at Langshot Bog, whilst Elstead Bog B would have been a small open water body during the Stadial. This herbaceous dominated landscape is consistent with that observed from river valley and coastal wetlands in SE England (Figure 13). There is also evidence for the development of patchy heathland, with Ericaceae, Calluna vulgaris and Empetrum nigrum ssp. nigrum type 
present. Dwarf-shrub heath is found in both low and high arctic vegetation communities (Razzhavin, 2012) and may offer a modern analogue for this landscape. Such a dwarf-shrub heathland community is also present locally at Bagshot (Groves, 2008) and Gatcombe Withy Bed (Scaife, 1987), wider afield in Britain at Llanilid (Walker et al., 2003), The Flasks 69 (Innes et al., 2009) and is recorded in other north-western Europe pollen diagrams (Verbruggen, 1979; Huntley and Birks, 1983; Bohncke et al., 1988; Walker et al., 1994). The presence of Empetrum nigrum ssp. nigrum type indicates a cool and cold climate as it (in addition to Calluna vulgaris and many Ericaceae species) tolerates windy exposed habitats and cold climatic conditions (Averis, 2013). Arboreal taxa primarily consisted of Betula (potentially the dwarf species Betula nana) with smaller amounts of Pinus, alongside Alnus and Corylus. The presence of Pinus, Alnus and Corylus warrant further examination, as their presence during this period is not universally observed at sites in NW Europe. These species may be present in the landscape, or may appear in the record due to contamination, long-distance transport, or reworking of older material (Cundill and Whittington, 1983; Edwards and Whittington, 2010). In this study, contamination is unlikely due to the use of a Russian corer, with material for analysis obtained from the centre of the core. Analysis of a pollen trap in the laboratory also indicated that there was no contamination by atmospheric pollen. Reworking of pollen also seems unlikely, as a limited range of unusual taxa are present, with reworking likely to lead to a broader range of anomalous pollen. There were also no obviously deteriorated pollen grains of specific taxa from either site, and these species have been identified at other sites in a regional setting. Studies of Pinus in Lateglacial contexts in Britain and Scandinavia have highlighted its susceptibility to longdistance pollen transportation (Day, 1996; Barnekow, 1999; Kullman, 2002; Birks et al., 2005) and without the presence of Pinus macrofossils, the exact relationship between longdistance transportation and local growth cannot be defined (Birks and Birks, 2000). However, studies have shown that percentage pollen counts of $5 \%$ (Bennett, 1995; McGeever and Mitchell, 2016) can to indicate local growth, and in some cases this can be as low as $0.4 \%$ (Froyd, 2005). With percentage values around $5 \%$ during this period at both 
490 Elstead Bog B and Langshot Bog, and its identification in Lateglacial deposits at a range of

491 other SE England sites (Figures 13-14) it is likely that there would have been small levels of

492 local growth in sheltered areas, alongside some level of long-distance transportation. The distinct size differentiation in the Pinus grains observed at Langshot Bog is thought to relate to natural variations within the pollen morphology. The species is likely to be Pinus sylvestris, as it is the only species of Pinus identified in Pleistocene/Holocene Britain (Bennett, 1984), and has a wide variation in total grain size (Desprat et al., 2015). The presence of Alnus at Elstead Bog B highlights its importance in this vegetation community and may have been present at the wetland/dryland interface (The Museum of London, 2000; Figures 13-14). Alnus is now becoming a more established component of the Lateglacial vegetation cover at sites across SE England dating to both the Windermere Interstadial and the Loch Lomond Stadial (Figure 14), including at Minchery Farm and Spartum Fen (Parker and Preston, 2014), West Silvertown (Wilkinson et al., 2000), Bramcote Green (Thomas et al., 1996) and Ockley Bog (Simmonds, 2017). Macrofossil records of Alnus have also been identified across Britain from as early as 14,700-14,000 cal. BP at Turker Beck, north-east England (Young et al., In Press), indicating that the presence of Alnus at these sites is not solely explained by long-distance transport of Alnus pollen. The presence of Alnus in SE England suggests that microclimates would have been hospitable enough to allow for its survival. This is also indicated by Corylus, present during the Lateglacial at Langshot Bog (>30\% probability at c. 12,800 cal. BP: Figure 14) and at the very end of the Loch Lomond Stadial at Elstead Bog B (>90\% from c. 12,000 cal. BP). Corylus has also been identified during the Loch Lomond Stadial at Minchery Farm and Spartum Fen (Parker and Preston, 2014) and Thursley Bog (Simmonds, 2017). The presence of Corylus is significant because although pollen values are relatively low (Figure 14), it may indicate that small stands were able to survive the climatic conditions of the stadial in SE England, and could represent a refugia location for the species in NW Europe. However, it presence during this period has also been attributed to long-distance transport (Birks and Mathewes, 1978), and without the

517 identification of Corylus macrofossils in SE England, this could also be applicable here. 
519 Figure 13. Vegetation synthesis for the Lateglacial and early Holocene period $(13,000-8000$ cal. BP) in SE England. Numbers refer to sites as follows:

LB-Langshot Bog; EBB-Elstead Bog B;1-Ockley Bog (Simmonds, 2017); 2-Thursley Bog (Simmonds, 2017); 3-Bagshot (Groves, 2008); 4-Elstead Bog A (Farr, 2008); 5Bramcote Green (Thomas et al., 1996; Branch and Green, 2004); 6-Nutfield Marsh (Farr, 2008); 7-Runnymede Bridge (Scaife, 2000a); 8-Farm Bog (Jennings and Smythe, 2000); 9-Holywell Coombe (Preece and Bridgland, 1999); 10-West Silvertown (Branch and Lowe, 1994; Wilkinson et al., 2000); 11-Colnbrook (Gibbard and Hall, 1982); 12-New Ford Road (Corcoran et al., 2011); 13-Meridian Point (Corcoran et al., 2011); 14-Spartum Fen (Parker and Preston, 2014); 15-Northmoor (Shotton et al., 1970); 16-Standlake (Sandford, 1965); 17-Queenborough (Pratt et al., 2003); 18-Munsley Peat bed (Scaife, 1980, 1982); 19-Intertidal peats in Hampshire (Long et al., 2000); 20-The Isle of Wight (Scaife, 1987); 21-Bouldnor Cliff (Momber et al., 2011); 22-Borthwood Farm (Scaife, 1987); 23Yarmouth Marsh (Scaife, Unpublished-b); 24-Panel Bridge (Waller, 1993); 25-Enfield Lock (Chambers et al., 1996); 26-Cothill (Day, 1991); 27-Farlington Marsh (Scaife, 2000b); 28-The Lower Brede and Tillingham (Waller and Long, 2010); 29-West Quay Road (Godwin, 1940; Nicholls and Scaife, 2008); 30-George V Docks (Godwin, 1940); 31-

During the Loch Lomond Stadial, the presence of micro-charcoal has provided a record of regional burning at both Elstead Bog B pre 11,820-11,400 cal. BP (WM-168, 2 $\sigma$ ) and Langshot Bog from 13,210-12,430 cal. BP (95\% probability, Start of Sequence, Figure 8), although a large decline is recorded at the start of the Loch Lomond Stadial from Langshot Bog at 12,940-12,420 cal. BP (95\% probability, 236 cm; Figure 5). Burning is observed across NW Europe, in Scotland (Edwards et al., 2000) and Denmark (Kolstrup, 1992) where 
activity and taphonomic processes due to a lack of data highlighting a single cause. Across SE England during the Lateglacial; at Minchery Farm (Parker and Preston, 2014) burning was attributed to lightning strikes, and at Holywell Coombe it was similarly identified as the product of natural, local fires (Preece and Bridgland, 1999). In both cases the fires were attributed to natural causes due to a paucity of regional archaeological evidence, as is also thought to be the case at Elstead Bog B and Langshot Bog. Evidence for the natural occurrence of wildfires in tundra-style ecosystems has been observed from modern studies (Gowlett, 2016), and the decreasing frequency of fires at Langshot Bog during the Loch Lomond Stadial is attributed to declining summer temperatures (Wein, 1976; Racine et al., 1985), and may also reflect changes in fuel availability as woodland declined. These burning events are significant, because burning in modern tundra ecosystems has shown that postfire soils can be $1-4^{\circ} \mathrm{C}$ warmer, with a deeper active layer than unburned soil (Rocha and Shaver, 2011), possibly creating improved growing conditions for warmth loving anomalous taxa, such as Corylus and Alnus.

Figure 14. Schematic diagram showing the presence of selected taxa (Pinus, Alnus and Corylus) and the timing of their first sustained presence in inland SE England. Pinus values of less than 5\% are not shown due to the long-distance transport of Pinus pollen.

The onset of the Holocene at 11,700 cal. BP (Walker et al., 2012) is marked by a rapid increase in Betula woodland, and low levels of other arboreal taxa including Juniperus type, Salix, Pinus, Corylus and Carpinus type at Langshot Bog and Elstead Bog B. A decline in herbaceous and heathland taxa are thought to be related to the reduced amount of light penetrating a denser Betula dominated canopy. Climatic warming at the start of the Holocene was rapid, with a rise in mean annual temperatures of $1.7-2.8^{\circ} \mathrm{C}$ per 100 years (Lowe and Walker, 2015) and in SE England, mean summer temperatures could have increased by up to $7.5^{\circ} \mathrm{C}$ in comparison to the Loch Lomond Stadial (Coope et al., 1998). 
warmer conditions, with lower levels of evaporation, there was a prolonged period of climatic instability lasting until $9790-9470 \mathrm{cal}$. BP (95\% probability, $96 \mathrm{~cm}$, Figure 5$)$ as woodland expansion continued, and herbaceous taxa declined. Due to the truncated sequence at Elstead Bog B, similar trends to that observed at Langshot Bog, such as this woodland expansion, are only observed in the record from Elstead Bog (Farr, 2008; Figure 15). Comparable vegetation trends, with a decline in herbaceous taxa alongside the dominance of Betula and Pinus woodland are also observed at Panel Bridge (Waller, 1993), Holywell Coombe (Kerney et al., 1980; Preece and Bridgland, 1998), and Wateringbury (Kerney et al., 1980), as well as many of the sites on the Hampshire Coast (Figure 13).

Two potential climatic events were identified in the early Holocene from the $\delta^{18} \mathrm{O}$ isotopic data at Langshot Bog. The 11,350-10,715 cal. BP (95\% probability, $162 \mathrm{~cm}$, Figure 5) period of decreased evaporation may relate to the Pre Boreal Oscillation (PBO) at 11,300-11,150 cal. BP (Björck et al., 1997) or ice rafted debris (IRD) event 8 (11,100 years BP) (Bond et al., 1997). Large-scale syntheses highlight a variable vegetation response to the PBO event around the Nordic Seas (Björck et al., 1997) and evidence for early Holocene IRD Events (Bond et al., 1997) are also variable both within SE England and around the Atlantic fringe of Europe (Wilkinson et al., 2000; Whittington et al., 2003; Garnett et al., 2004; Farr, 2008; Groves, 2008; Ghilardi and O'Connell, 2013), related to a paucity of (continuous) records, a lack of multi-proxy studies and poor sediment deposition rates. However, some evidence is observed in north-west Europe for either the PBO or the 11,100 years BP event from oxygen isotope values of Lough Inchiquin, Ireland (Diefendorf et al., 2006) and Crudale Meadow (Whittington et al., 2015), tufa at Wateringbury (Garnett et al., 2004) and from Hawes Water at both 11,400 cal. BP and 11,200 cal. BP (Lang et al., 2010). At Kingbeekdal in The Netherlands, cooling is identified between 11,400 and 11,300 cal. BP in both oxygen isotopes and the pollen record, with a decrease in Betula and subsequent opening of the woodland (Bohncke and Hoek, 2007). The second period of decreased evaporation, dated 

to $10,850-10,520 \mathrm{cal}$. BP (95\% probability, $140 \mathrm{~cm}$, Figure 5) does not appear to tie in with

614 IRD Event 7 (10,300 years BP) (Bond et al. 1997) but lower temperatures (based on chironomid data) are observed from 10,400 cal. BP at Hawes Water (Lang et al., 2010). Cooler, moister and less seasonal conditions observed from lake records in the Faroe Islands at 10,600, 10,450 and 10,300 cal. BP (Hannon et al., 2003; Andresen et al., 2007) and an advance in glacier limits was also observed in Western Norway, dated to 10,235 cal. BP (Nesje et al., 2004). These studies all serve to highlight widespread climatic instability across a broad period. Identifying these events at Langshot Bog through the isotopic data is significant, as neither period of climatic instability appears clearly in either in the pollen record or $\delta^{2} \mathrm{H}$ values, although general climatic instability could have assisted the widespread Pinus woodland development during this period. These results suggest that there may have been a climatic downturn at Langshot Bog around both the PBO and $10,850-10,520$ cal. $B P(95 \%$ probability, $140 \mathrm{~cm}$, Figure 5$)$, but the magnitude or duration of either event was not enough to trigger widespread vegetation change.

Figure 15. Elstead Bog: selected taxa percentage pollen diagram, after Farr (2008).

The sporadic occurrence of Corylus, during the Late Glacial and Early Holocene, alongside both coniferous (Pinus) and deciduous (Betula) taxa, may indicate the presence of brown earth soils, able to support this mixed woodland. This woodland continued at Langshot Bog until 10,440-10,230 cal. BP (95\% probability, LB4/5, Figure 8 ) and represents a pattern observed across SE England (Chambers et al., 1996; Preece and Bridgland, 1999; Scaife, 2001; Corcoran et al., 2011). From this time onwards, the records from Langshot Bog and Elstead Bog indicate woodland diversification: the colonisation of thermophilous species, specifically the rapid expansion of Corylus, followed by Ulmus and Quercus and a reduction in Pinus due to increased competition from deciduous trees. This pattern is recorded at inland and coastal wetlands in SE England including Wateringbury (Kerney et al., 1980), Holywell Coombe (Kerney et al., 1980; Preece and Bridgland, 1998), Lewes I and II 
641 (Thorley, 1981), Panel Bridge (Waller, 1993), Brede Bridge (Waller and Marlow, 1994),

642 Horsemarsh Sewer (Waller et al., 1999), Mount Caburn (Waller and Hamilton, 2000; Waller

643 and Long, 2010), Queenborough (Pratt et al., 2003) and Tilling Green, Rye (Waller and

644 Kirby, 2002). An increase in Poaceae, Calluna vulgaris and other herbaceous taxa implies

645 clearings or openings in the woodland canopy in contrast to the dense Pinus/Betula

646 woodland of the earliest Holocene.

647

648 The decline of Pinus and dominance of Corylus at Langshot Bog and across SE England 649 warrants further discussion, because a number of studies have highlighted the importance of 650 hazelnuts during the Mesolithic period both in Britain (Radley et al., 1974; Godwin, 1975) 651 and in Europe (Holst, 2010). It has been suggested that Mesolithic hunter-gatherers may 652 have contributed to this spread, by removing shading species to promote Corylus flowering 653 and expansion (Mithen et al., 2001) or undertaking selective pruning to produce greater nut 654 yield (Groß et al., 2018). A significant Mesolithic presence around the Elstead Bog sites is suggested from the archaeological record and therefore these human groups may have facilitated the expansion of Corylus around these sites. However, a lack of evidence for Mesolithic sites around the Langshot Bog site, and across the region more generally (Simmonds et al., 2019), together with a lack of burning and other anthropogenic indicators at the time of Corylus expansion at both Langshot Bog and Elstead Bog, suggests that the expansion is related to climatic amelioration and not human manipulation. This would include warmer conditions, extended growth seasons and a more stable climate (Tallantire, 2002), and therefore changes in vegetation composition and the formation of woodland clearings are unlikely to have been anthropogenic in origin. At Elstead Bog, there is no immediate decline in Pinus with the onset of deciduous woodland expansion, a pattern observed both at Conford (Groves et al., 2012) and in the Glynde Valley (Waller and Hamilton, 2000; Waller and Long, 2010) and attributed to the freely draining sandy geology. These substrates can often lead to low nutrient level soil, whereby invading species would have had less of an advantage over Pinus, allowing it to survive longer within the local woodland. Prolonged 
regular burning would have also influenced the Pinus record, as fires consume the humus soil layer, allowing Pinus to thrive in the bare mineral soil whilst other species struggle to survive (Richardson, 2000).

At Elstead Bog, a decline in several taxa is observed from 9290-9000 cal. BP (Wk-1422, 2б) including Betula, Corylus and Ulmus, whilst Pinus, Poaceae and ferns increase. This indicates wetter conditions, possibly connected to either the 9400-year BP IRD Event (Event 6 - Bond et al., 1997), or the onset of the $9000-8000$ cal. BP rapid climate change period (Mayewski et al., 2004). At this time, the isotopic record from Langshot Bog initially indicates a trend toward decreasing evaporation from 9540-9480 cal. BP (95\% probability, wm95) followed by a trend toward increased evaporation and wetter conditions from 9010-8520 cal. BP (95\% probability, $76 \mathrm{~cm}$, Figure 5) until at least $8430-8350$ cal. BP (95\% probability, wm65, Figure 8). Again, palaeoenvironmental evidence for either climatic event from sites in SE England is sparse. However, across Britain, lower temperatures are observed at 9300 cal. BP from chironomid data at Hawes Water (Lang et al., 2010) and wetter conditions identified from Sphagnum records at 9200 cal. BP from Bolton Fell Moss (Barber et al., 2003). A climatic event following the 9400 -year BP IRD event is also observed from a speleothem record in Ireland, where variability continues until 8800 cal. BP (McDermott et al., 2001). As with IRD Events 8 and 7, IRD Event 6 did not appear to result in identifiable alterations to the vegetation composition at Langshot Bog, and although some woodland decline was identified at Elstead Bog, it suggests these events were not definitively of sufficient duration or magnitude to result in expansive modification of the vegetation cover.

\section{Conclusions}

Palaeoenvironmental records from lowland, inland wetlands in SE England are rare, with most sites situated in riverine or coastal settings. There is also a paucity of sites containing organic deposits formed during the Loch Lomond Stadial. Langshot Bog and Elstead Bog B are therefore highly significant for furthering the understanding of vegetation dynamics 
during this period of climatic instability in Britain and NW Europe. The use of a multi-proxy approach, focusing on the Lateglacial and early Holocene, has led to the enhancement of previously identified biostratigraphic zones (Branch and Green, 2004; Groves, 2008; Groves et al., 2012) while providing greater detail and more robust timings for climatic events, vegetation change, species abundance and composition during this period. Significantly, there is evidence for Pinus, Alnus and Corylus as components of the Late Glacial vegetation around these sites. Although the presence of these species could be due to long-distance transport of pollen, it is not thought to fully account for the observed distributions, which are considered likely to have grown in sheltered parts of the landscape, perhaps offering insights into Glacial refugia locations. This is an area where the identification of plant macrofossils would assist greatly, as observed with Alnus at Turker Beck. Woodland development during the Holocene is characterised by the expansion of a dense Betula and Pinus forest. Mixed thermophilous woodland expansion is then observed, with a reduction in Pinus, apart from at sites with freely draining geologies or frequent burning events, where Pinus forms a component of the mixed woodland. The use of stable isotope records alongside pollen and sedimentological analysis has highlighted possible short-term climatic events, the first of which may chronologically correlate with the Pre-Boreal Oscillation, or the 11,100-year BP IRD event. A second, similar magnitude event seems too early for the 10,300-year BP IRD event, and may represent part of a period of climatic uncertainty, as represented by various studies in NW Europe which highlight climatic change across 10,800-10,200 cal. BP. A longer trend towards decreasing evaporation from 9540-9480 cal. BP (95\% probability, thermophilous taxa, potentially indicating a more severe or prolonged event than earlier periods of short-term climate change. These climatic shifts do not appear to be consistently observed in the vegetation record, and therefore the use of stable-isotope records for identifying these short-term shifts in climate is significant. Further studies should attempt to 
identify these short-term climatic shifts, which would allow for a greater understanding of the timing and impact of these early-Holocene events.

\section{Acknowledgements}

This research was supported by a PhD grant, funded by The Faculty of Science at the University of Reading, Historic England, Surrey County Council and Surrey Archaeology Society. The radiocarbon dating programme was funded by Historic England. Access to Elstead Bog B was facilitated by Derrick and Roger Pride. Stephen Fry and Surrey Wildlife Trust permitted access to Chobham Common (Langshot Bog). Analysis of samples in the Chemical Analytic Facility at the University of Reading was aided by Yan Gao. Tony Howe and his team helped access the Surrey County Council Historic Environment Record. An anonymous referee provided helpful and valuable comments on an earlier draft of this publication.

\section{References}

Ambers, J., 2000. Scientific Dating Evidence: Radiocarbon sample selection and measurement in: Needham, S.P. (Ed.), Runnymede Bridge Research Excavations Volume 1. The Passage of the Thames Holocene Environment and Settlement at Runnymede. London: The British Museum Press, 90-91.

Andresen, C.S., Björck, S., Jessen, C., Rundgren, M., 2007. Early Holocene terrestrial climatic variability along a North Atlantic Island transect: palaeoceanographic implications. Quaternary Science Reviews 26, 1989-1998. https://doi.org/10.1016/j.quascirev.2006.12.017

Averis, B., 2013. Plants and Habitats: An Introduction to Common Plants and Their Habitats in Britain and Ireland. Norwich: Swallowtail Print Ltd. 
Barber, K.E., Chambers, F.M., Maddy, D., 2003. Holocene palaeoclimates from peat stratigraphy: macrofossil proxy climate records from three oceanic raised bogs in England and Ireland. Quaternary Science Reviews 22, 521-539. https://doi.org/10.1016/S02773791(02)00185-3

Barber, K.E., Clark, M.J., 1987. Cranes Moor, New Forest: palynology and macrofossil stratigraphy, in: Barber, K.E. (Ed.), Wessex and the Isle of Wight Field Guide. Cambridge: Quaternary Research Association, 33-44.

Barnekow, L., 1999. Holocene tree-line dynamics and inferred climatic changes in the Abisko area, northern Sweden, based on macrofossil and pollen records. The Holocene 9, 253-265. 10.1191/095968399676322637

Barton, N., 2009. The Lateglacial or Late and Final Upper Palaeolithic Colonization of Britain, in: Hunter, J., Ralston, I. (Eds.), The Archaeology of Britain. An Introduction from the Upper Palaeolithic to the Industrial Revolution. London: Routledge, 18-52.

Barton, R.N.E., Roberts, A., 2004. The Mesolithic Period in England: Current Perspectives and New Research, in: Saville, A. (Ed.), Mesolithic Scotland and Its Neighbours: The Early Holocene Prehistory of Scotland, its British and Irish Context and some Northern European Perspectives. Edinburgh: The Society of Antiquaries of Scotland, 339-358.

Batchelor, C.R., Branch, N.P., Allison, E.A., Austin, P.A., Bishop, B., Brown, A.D., Elias, S.A., Green, C.P., Young, D.S., 2014. The timing and causes of the Neolithic elm decline: New evidence from the Lower Thames Valley (London, UK). Environmental Archaeology 19, 263-290. doi:10.1179/1749631414Y.0000000031 
Batchelor, C.R., Branch, N.P., Carew, T., Elias, S.E., Gale, R., Lafferty, G.E., Matthews, I.P., Meddens, F., Vaughan-Williams, A., Webster, L.A., Young, D.S., 2019. Middle-Holocene environmental change and archaeology in coastal wetlands: Further implications for our understanding of the history of Taxus woodland. The Holocene 30, 300-314. https://doi.org/10.1177/0959683619883028

Batchelor, C.R., Green, C., Young, D., Austin, P., Cameron, N., Elias, S., 2015. Prehistoric landscapes beneath the London Cable Car. London Archaeologist 14, 65-72. https://doi.org/10.5284/1000168

Batchelor, C.R., Green, C.P., Young, D.S., Walker, T., Allott, L., 2012. Surrey House, 20 Lavington Street, London Borough of Southwark, SE1 ONZ (Site Code: LVI11):

Environmental Archaeological Analysis Report. Reading: Quaternary Scientific (QUEST), University of Reading.

Beerling, D.J., 1998. Salix herbacea L. Journal of Ecology 86, 872-895. https://doi.org/10.1046/j.1365-2745.1998.8650872.x

Bengtsson, L., Enell, M., 1986. Chemical analysis, in: Berglund, B.E. (Ed.), Handbook of Holocene Palaeoecology and Palaeohydrology. Chichester: Wiley, 423-454.

Bennett, K., 1995. Post-glacial dynamics of pine (Pinus sylvestris L.) and pinewoods in Scotland, in: Aldhous, J. (Ed.), Our pinewood heritage. Inverness: Forestry Commission, Royal Society for the Protection of Birds, Scottish Natural Heritage, 23-39.

Bennett, K.D., 1983. Devensian Late-Glacial and Flandrian vegetational history at Hockham Mere, Norfolk, England. I. Pollen percentages and concentrations. The New Phytologist 95, 457-487. https://doi.org/10.1111/j.1469-8137.1983.tb03512.x 
Bennett, K.D., 1984. The post-glacial history of Pinus sylvestris in the British Isles. Quaternary Science Reviews 3, 133-155. http://dx.doi.org/10.1016/0277-3791(84)90016-7

Bennett, K.D., Willis, K.J., 2002. Pollen, in: Smol, J.P., Birks, H.J., Last, W.M. (Eds.), Tracking Environmental Change Using Lake Sediments. Dordrecht, The Netherlands: Kluwer Academic Publishers, 5-32.

Birks, H., Mathewes, R., 1978. Studies in the Vegetational History of Scotland. New Phytologist 80, 455-484. https://doi.org/10.1111/j.1469-8137.1978.tb01579.x

Birks, H.H., Birks, H.J.B., 2000. Future uses of pollen analysis must include plant macrofossils. Journal of Biogeography 27, 31-35. https://doi.org/10.1046/j.1365$2699.2000 .00375 . x$

Birks, H.H., Larsen, E., Birks, H.J.B., 2005. Did tree-Betula, Pinus and Picea survive the last glaciation along the west coast of Norway? A review of the evidence, in light of Kullman (2002). Journal of Biogeography 32, 1461-1471. https://doi.org/10.1111/j.13652699.2005.01287.x

Birks, H.J.B., 1965. Late-Glacial deposits at Bagmere, Cheshire, and Chat Moss, Lancashire. New Phytologist 64, 270-281. https://doi.org/10.1111/j.14698137.1965.tb05396.x

Birks, H.J.B., 1968. The Identification of Betula nana Pollen. New Phytologist 67, 309-314. https://doi.org/10.1111/j.1469-8137.1968.tb06386.x

Birks, H.J.B., 1989. Holocene isochrone maps and patterns of tree-spreading in the British Isles. Journal of Biogeography 16, 503-540. http://dx.doi.org/10.2307/2845208 
Björck, S., Rundgren, M., Ingólfsson, Ó., Funder, S., 1997. The Preboreal oscillation around the Nordic Seas: terrestrial and lacustrine responses. Journal of Quaternary Science 12, 455-465. https://doi.org/10.1002/(SICI)1099-1417(199711/12)12:6<455::AIDJQS316>3.0.CO;2-S

Blackburn, K.B., 1952. The dating of a deposit containing an elk skeleton found at Neasham near Darlington, County Durham. New Phytologist 51, 364-377. https://doi.org/10.1111/j.1469-8137.1952.tb06145.x

Bohncke, S., Wijmstra, L., Woude, J.V.D., Sohl, H., 1988. The Late-Glacial infill of three lake successions in The Netherlands: Regional vegetational history in relation to NW European vegetational developments. Boreas 17, 385-402. https://doi.org/10.1111/j.15023885.1988.tb00970.x

Bohncke, S.J.P., Hoek, W.Z., 2007. Multiple oscillations during the Preboreal as recorded in a calcareous gyttja, Kingbeekdal, The Netherlands. Quaternary Science Reviews 26, 19651974. https://doi.org/10.1016/j.quascirev.2007.02.017

Bond, G., Showers, W., Cheseby, M., Lotti, R., Almasi, P., de Menocal, P., Priore, P., Cullen, H., Hajdas, I., Bonani, G., 1997. A pervasive millennial-scale cycle in North Atlantic Holocene and glacial climates. Science 278, 1257-1266. https://doi.org/10.1126/science.278.5341.1257

Branch, N.P., Batchelor, C.R., Cameron, N.G., Coope, G.R., Densem, R., Gale, R., Green, C.P., Williams, A.N., 2012. Holocene environmental changes in the Lower Thames Valley, London, UK: Implications for understanding the history of Taxus woodland. The Holocene 22, 1143-1158. https://doi.org/10.1177/0959683612441805 
Branch, N.P., Canti, M.G., Clark, P., Turney, C., 2005. Environmental Archaeology. London: Hodder Education.

Branch, N.P., Green, C.P., 2004. Environmental history of Surrey, in: Cotton, J., Crocker, G., Graham, A. (Eds.), Aspects of Archaeology and History in Surrey: Towards a Research Framework for the County. Guildford: Surrey Archaeological Society, 1-18.

Branch, N.P., Lowe, J.J., 1994. Bramcote Green Redevelopment archaeological project 1992/3, Palynology. London: Archaeoscape, University of London.

Bronk Ramsey, C., 1995. Radiocarbon Calibration and Analysis of Stratigraphy: The OxCal Program. Radiocarbon 37, 425-430. https://doi.org/10.1017/S0033822200030903

Bronk Ramsey, C., 2008. Deposition models for chronological records. Quaternary Science Reviews 27, 42-60. https://doi.org/10.1016/j.quascirev.2007.01.019

Bronk Ramsey, C., 2009. Bayesian analysis of radiocarbon dates. Radiocarbon 51, 337360. https://doi.org/10.1017/S0033822200033865

Bronk Ramsey, C., Lee, S., 2013. Recent and planned developments of the program OxCal. Radiocarbon 55, 720-730. https://doi.org/10.1017/S0033822200057878

Brooks, S.J., Birks, H.J.B., 2000. Chironomid-inferred Late-glacial air temperatures at Whitrig Bog, Southeast Scotland. Journal of Quaternary Science 15, 759-764. https://doi.org/10.1002/1099-1417(200012)15:8\%3C759::AID-JQS590\%3E3.0.CO;2-V 
855 Carter, R.J., 2001. New evidence for seasonal human presence at the Early Mesolithic site 856 of Thatcham, Berkshire, England. Journal of Archaeological Science 28, 1055-1060.

857 https://doi.org/10.1006/jasc.2000.0643

858 Chambers, F.M., Mighall, T.M., Keen, D.H., 1996. Early Holocene pollen and molluscan 859 records from Enfield Lock, Middlesex, UK. Proceedings of the Geologists' Association 107, 860 1-14. https://doi.org/10.1016/S0016-7878(96)80063-0

861 Chapin, F.S., III, Chapin, M.C., 1980. Revegetation of an Arctic disturbed site by native 862 tundra species. Journal of Applied Ecology 17, 449-456. DOI: 10.2307/2402339

863 Chisham, C., 2004. Early Mesolithic human activity and environmental change: A case study 864 of the Kennet Valley. PhD Thesis. University of Reading: Department of Archaeology.

865 Clapham, A., Tutin, T.G., Moore, D., 1987. Flora of the British Isles. Cambridge: Cambridge 866 University Press.

867 Cook, C., 1961. Sparganium in Britain. Watsonia 5, 1-10.

868 Coope, G.R., Lemdahl, G., Lowe, J.J., Walkling, A., 1998. Temperature gradients in northern 869 Europe during the last glacial-Holocene transition (14-9 14C kyr BP) interpreted from 870 coleopteran assemblages. Journal of Quaternary Science 13, 419-433.

871 https://doi.org/10.1002/(SICl)1099-1417(1998090)13:5\%3C419::AID-JQS410\%3E3.0.CO;2872 D

873 Corcoran, J., Halsey, C., Spurr, G., Burton, E., Jamieson, D., 2011. Mapping past 874 landscapes in the lower Lea valley. A geoarchaeological study of the quaternary sequence. 875 London: Museum of London Archaeology. 
876 Cundill, P., Whittington, G., 1983. Anomalous arboreal pollen assemblages in Late

877 Devensian and Early Flandrian deposits at Creich Castle, Fife, Scotland. Boreas 12, 297-

879 Davis, B.A.S., Brewer, S., Stevenson, A.C., Guiot, J., Data Contributors, 2003. The 880 temperature of Europe during the Holocene reconstructed from pollen data. Quaternary

881 Science Reviews 22, 1701-1716. https://doi.org/10.1016/S0277-3791(03)00173-2

882

Day, P., 1996. Devensian Late-glacial and early Flandrian environmental history of the Vale of Pickering, Yorkshire, England. Journal of Quaternary Science 11, 9-24.

Day, S., 1991. Post-glacial vegetational history of the Oxford region. New Phytologist 119, 445-470. https://doi.org/10.1111/j.1469-8137.1991.tb00045.x

Desprat, S., Díaz Fernández, P.M., Coulon, T., Ezzat, L., Pessarossi-Langlois, J., Gil, L., Morales-Molino, C., Sánchez Goñi, M.F., 2015. Pinus nigra (European black pine) as the dominant species of the last glacial pinewoods in south-western to central lberia: a morphological study of modern and fossil pollen. Journal of Biogeography 42, 1998-2009. https://doi.org/10.1111/jbi.12566

Diefendorf, A.F., Patterson, W.P., Mullins, H.T., Tibert, N., Martini, A., 2006. Evidence for high-frequency late Glacial to mid-Holocene $(16,800$ to 5500 cal yr B.P.) climate variability from oxygen isotope values of Lough Inchiquin, Ireland. Quaternary Research 65, 78-86. https://doi.org/10.1016/j.yqres.2005.08.001

Edwards, K.J., Whittington, G., 2010. Lateglacial palaeoenvironmental investigations at Wester Cartmore Farm, Fife and their significance for patterns of vegetation and climate 
change in east-central Scotland. Review of Palaeobotany and Palynology 159, 14-34. https://doi.org/10.1016/j.revpalbo.2009.10.004

Edwards, K.J., Whittington, G., Tipping, R., 2000. The incidence of microscopic charcoal in late glacial deposits. Palaeogeography, Palaeoclimatology, Palaeoecology 164, 247-262. http://dx.doi.org/10.1016/S0031-0182(00)00189-9

Eley, Y., Dawson, L., Black, S., Andrews, J., Pedentchouk, N., 2014. Understanding 2 H/1 H systematics of leaf wax n-alkanes in coastal plants at Stiffkey saltmarsh, Norfolk, UK. Geochimica et Cosmochimica Acta 128, 13-28. https://doi.org/10.1016/j.gca.2013.11.045

Farr, L.R., 2008. Enhancing our understanding of Mesolithic environments and resource exploitation in south-east England. A case study from Surrey. PhD Thesis. Royal Holloway, University of London: Department of Geography.

Fitter, A., 1987. Collins New Generation Guide Wild Flowers of Britain and Northern Europe. London: William Collins Sons \& Co. Ltd.

Freeman, S.P., Cook, G.T., Dougans, A.B., Naysmith, P., Wilcken, K.M., Xu, S., 2010. Improved SSAMS performance. Nuclear Instruments and Methods in Physics Research Section B: Beam Interactions with Materials and Atoms 268, 715-717. https://doi.org/10.1016/j.nimb.2009.10.012

French, C., Scaife, R., Allen, M.J., Parker Pearson, M., Pollard, J., Richards, C., Thomas, J., Welham, K., 2012. Durrington Walls to West Amesbury by way of Stonehenge: a major transformation of the Holocene landscape. The Antiquaries Journal 92, 1-36. $10.1017 / S 0003581512000704$ 
Froyd, C.A., 2005. Fossil stomata reveal early pine presence in Scotland: Implications for postglacial colonization analyses. Ecology 86, 579-586. https://doi.org/10.1890/04-0546

Gallois, R.W., 1965. British Regional Geology The Wealden District. London: Her Majesty's Stationary Office.

Garnett, E.R., Andrews, J.E., Preece, R.C., Dennis, P.F., 2004. Climatic change recorded by stable isotopes and trace elements in a British Holocene tufa. Journal of Quaternary Science 19, 251-262. https://doi.org/10.1002/jqs.842

Ghilardi, B., O'Connell, M., 2013. Early Holocene vegetation and climate dynamics with particular reference to the 8.2 ka event: pollen and macrofossil evidence from a small lake in western Ireland. Vegetation History and Archaeobotany 22, 99-114. https://doi.org/10.1007/s00334-012-0367-x

Gibbard, P.L., Hall, A.R., 1982. Late Devensian river deposits in the Lower Colne valley, West London, England. Proceedings of the Geologists' Association 93, 291-299. https://doi.org/10.1016/S0016-7878(82)80005-9

Godwin, H., 1940. Pollen analysis and forest history of England and Wales. New Phytologist 39, 370-400. https://doi.org/10.1111/j.1469-8137.1940.tb07149.x

Godwin, H., 1945. A submerged peat bed in Portsmouth Harbour. Data for the study of PostGlacial History. IX. New Phytologist 44, 152-155. https://doi.org/10.1111/j.14698137.1945.tb05028.x 
937 Godwin, H., 1975. History of the natural forests of Britain: establishment, dominance and

938 destruction. Philosophical Transactions of the Royal Society B: Biological Sciences 271, 47939 67. https://doi.org/10.1098/rstb.1975.0034

940 Gowlett, J.A.J., 2016. The discovery of fire by humans: a long and convoluted process.

941 Philosophical Transactions of the Royal Society of London B: Biological Sciences 371.

$942 \quad 10.1098 /$ rstb.2015.0164

943 Grimm, E.C., 1987. CONISS: a FORTRAN 77 program for stratigraphically constrained 944 cluster analysis by the method of incremental sum of squares. Computers \& Geosciences 945 13, 13-35. https://doi.org/10.1016/0098-3004(87)90022-7

946 Grimm, E.C., 2011. TILIA 1.7.16. Springfield: Illinois state museum.

947 Groß, D., Lübke, H., Schmölcke, U., Zanon, M., 2018. Early Mesolithic activities at ancient 948 Lake Duvensee, northern Germany. The Holocene 29, 197-208.

949 https://doi.org/10.1177\%2F0959683618810390

950 Groves, J.A., 2008. Late Quaternary vegetation history of the acidic lithologies of South East

951 England. PhD Thesis. Kingston University: Geography, Geology and Environment.

952 Groves, J.A., Waller, M.P., Grant, M.J., 2012. Long-term development of a cultural 953 landscape: the origins and dynamics of lowland heathland in southern England. Vegetation 954 History and Archaeobotany 21, 453-470. https://doi.org/10.1007/s00334-012-0372-0

955 Hall, A., 1978. Some new palaeobotanical records for the British Ipswichian interglacial. New 956 Phytologist 81, 805-812. https://doi.org/10.1111/j.1469-8137.1978.tb01655.x 
Hannon, G.E., Bradshaw, R.H.W., Wastegård, S., 2003. Rapid vegetation change during the early Holocene in the Faroe Islands detected in terrestrial and aquatic ecosystems. Journal of Quaternary Science 18, 615-619. 10.1002/jqs.783

Healy, F., Lobb, S.J., Heaton, M., 1992. Excavations of a Mesolithic site at Thatcham, Berkshire. Proceedings of the Prehistoric Society 58, 41-76. https://doi.org/10.1017/S0079497X00004096

Holst, D., 2010. Hazelnut economy of early Holocene hunter-gatherers: a case study from Mesolithic Duvensee, northern Germany. Journal of Archaeological Science 37, 2871-2880. https://doi.org/10.1016/j.jas.2010.06.028

Huntley, B., Birks, H.J.B., 1983. An Atlas of Past and Present Pollen Maps for Europe: 013000 Years Ago. Cambridge: Cambridge University Press.

Innes, J.B., Blackford, J.J., Simmons, I., 2010. Woodland disturbance and possible land-use regimes during the Late Mesolithic in the English uplands: pollen, charcoal and non-pollen palynomorph evidence from Bluewath Beck, North York Moors, UK. Vegetation History and Archaeobotany 19, 439-452.

Innes, J.B., Blackford, J.J., Simmons, I.G., 2004. Testing the integrity of fine spatial resolution palaeoecological records: microcharcoal data from near-duplicate peat profiles from the North York Moors, UK. Palaeogeography, Palaeoclimatology, Palaeoecology 214, 295-307. http://dx.doi.org/10.1016/j.palaeo.2004.04.004

Innes, J.B., Rutherford, M.M., O’Brien, C.E., Bridgland, D.R., Mitchell, W.A., Long, A.J., 2009. Late Devensian environments in the Vale of Mowbray, North Yorkshire, UK: evidence 
978 from palynology. Proceedings of the Geologists' Association 120, 199-208.

979 https://doi.org/10.1016/j.pgeola.2009.08.007

980 Jennings, S., Smythe, C., 2000. Six thousand years of history preserved in Farm Bog, in:

981 Drakeford, T., Sutcliffe, U. (Eds.), Wimbledon Common and Putney Heath: a natural history

982 London: Wimbledon and Putney Commons Conservators, 28-39.

983 Jowsey, P.C., 1966. An Improved Peat Sampler. New Phytologist 65, 245-248.

984 Kerney, M.P., Preece, R.C., Turner, C., 1980. Molluscan and plant biostratigraphy of some 985 Late Devensian and Flandrian deposits in Kent. Philosophical Transactions of the Royal 986 Society of London. Series B, Biological Sciences 291, 1-43.

987 https://doi.org/10.1098/rstb.1980.0126

988

989

990

991

992

993

994

995

996

997

998

Kolstrup, E., 1980. Climate and statigraphy in northwestern Europe between 30,000 B.P., 13,000 B.P. with special reference to the Netherlands. Meded. Rijks Geol. Dienst 32 181253.

Kolstrup, E., 1992. Danish pollen records radiocarbon-dated to between 50000 and 57000 yr BP. Journal of Quaternary Science 7, 163-172. https://doi.org/10.1002/jqs.3390070207

Kullman, L., 2002. Boreal tree taxa in the central Scandes during the Late-Glacial: implications for Late-Quaternary forest history. Journal of Biogeography 29, 1117-1124. https://doi.org/10.1046/j.1365-2699.2002.00743.x

Lang, B., Bedford, A., Brooks, S.J., Jones, R.T., Richardson, N., Birks, H.J.B., Marshall, J.D., 2010. Early-Holocene temperature variability inferred from chironomid assemblages at Hawes Water, northwest England. The Holocene 20, 943-954. 
Leider, A., Hinrichs, K.-U., Schefuß, E., Versteegh, G.J.M., 2013. Distribution and stable

1000 isotopes of plant wax derived n-alkanes in lacustrine, fluvial and marine surface sediments 1001 along an Eastern Italian transect and their potential to reconstruct the hydrological cycle. 1002 Geochimica et Cosmochimica Acta 117, 16-32. https://doi.org/10.1016/j.gca.2013.04.018

1003 Lewis, J.S.C., 1991. A Late Glacial and early Post-Glacial site at Three Ways Wharf, 1004 Uxbridge, England: interim report, in: Barton, N., Roberts, A.J., Roe, D.A. (Eds.), The Late 1005 Glacial in North-West Europe CBA Research Report, 246-255.

1006

1007

1008

1009

1010

1011

1012

1013

1014

1015

1016

1017 Lewis, J.S.C., Rackham, J., 2011. Three Ways Wharf, Uxbridge: a Late glacial and Early Holocene hunter-gatherer site in the Colne valley. London: Museum of London Archaeology.

Lewis, J.S.C., Wiltshire, P.E.J., Macphail, R., 1992. A Late Devensian/Early Flandrian site at Three Ways Wharf, in: Needham, S., Macklin, M.G. (Eds.), Alluvial Archaeology in Britain. Oxford: Oxbow Books, 249-260.

Long, A.J., Scaife, R.G., Edwards, R.J., 2000. Stratigraphic architecture, relative sea-level, and models of estuary development in southern England: new data from Southampton Water. Geological Society, London, Special Publications 175, 253-279. 10.1144/gsl.sp.2000.175.01.19

Lowe, J.J., Lowe, S., 1989. Interpretation of the pollen stratigraphy of Late Devensian lateglacial and early Flandrian sediments at Llyn Gwernan, near Cader Idris, North Wales. New Phytologist 113, 391-408. https://doi.org/10.1111/j.1469-8137.1989.tb02417.x Lowe, J.J., Walker, M.J., 2015. Reconstructing Quaternary Environments. Abingdon: 1019 Routledge. 
Lowe, J.J., Walker, M.J.C., Scott, E.M., Harkness, D.D., Bryant, C.L., Davies, S.M., 2004. A coherent high-precision radiocarbon chronology for the Late-glacial sequence at Sluggan Bog, Co. Antrim, Northern Ireland. Journal of Quaternary Science 19, 147-158. https://doi.org/10.1002/jqs.814

Magill, C.R., Ashley, G.M., Freeman, K.H., 2013. Ecosystem variability and early human habitats in eastern Africa. Proceedings of the National Academy of Sciences 110,11671174. 10.1073/pnas. 1206276110

Marshall, J.D., Jones, R.T., Crowley, S.F., Oldfield, F., Nash, S., Bedford, A., 2002. A high resolution Late-Glacial isotopic record from Hawes Water, Northwest England: Climatic oscillations: calibration and comparison of palaeotemperature proxies. Palaeogeography, Palaeoclimatology, Palaeoecology 185, 25-40. https://doi.org/10.1016/S00310182(02)00422-4

Mayewski, P.A., Rohling, E.E., Stager, J.C., Karlén, W., Maasch, K.A., Meeker, L.D., Meyerson, E.A., Gasse, F., van Kreveld, S., Holmgren, K., Lee-Thorp, J., Rosqvist, G., Rack, F., Staubwasser, M., Schneider, R.R., Steig, E.J., 2004. Holocene climate variability. Quaternary Research 62, 243-255. https://doi.org/10.1016/j.yqres.2004.07.001

Mayle, F.E., Lowe, J.J., Sheldrick, C., 1997. The Late Devensian Lateglacial palaeoenvironmental record from Whitrig Bog, SE Scotland. 1. Lithostratigraphy, geochemistry and palaeobotany. Boreas 26, 279-295. https://doi.org/10.1111/j.15023885.1997.tb00856.x

McDermott, F., Mattey, D.P., Hawkesworth, C., 2001. Centennial-Scale Holocene Climate Variability Revealed by a High-Resolution Speleothem $\delta 180$ Record from SW Ireland. Science 294, 1328-1331. 10.1126/science.1063678 
McGeever, A.H., Mitchell, F.J.G., 2016. Re-defining the natural range of Scots Pine (Pinus sylvestris L.): a newly discovered microrefugium in western Ireland. Journal of Biogeography 43, 2199-2208. https://doi.org/10.1111/jbi.12761

Mithen, S., Finlay, N., Carruthers, W., Carter, S., Ashmore, P., 2001. Plant use in the Mesolithic: Evidence from Staosnaig, Isle of Colonsay, Scotland. Journal of Archaeological Science 28, 223-234. https://doi.org/10.1006/jasc.1999.0536

Momber, G., Scaife, R., Nayling, N., 2011. Environmental Change in the cultural landscape across the valley, in: Momber, G., Tomalin, D., Scaife, R., Satchell, J., Gillespie, J. (Eds.), Mesolithic occupation at Bouldnor Cliff and the submerged prehistoric landscapes of the Solent. York: Council for British Archaeology, 105-112.

Moore, P.D., Webb, J.A., Collinson, M.E., 1991. Pollen Analysis, 2nd Edition ed. Oxford: Blackwell Scientific Publications.

Nesje, A., Dahl, S.O., Bakke, J., 2004. Were abrupt Lateglacial and early-Holocene climatic changes in northwest Europe linked to freshwater outbursts to the North Atlantic and Arctic Oceans? The Holocene 14, 299-310. 10.1191/0959683604hl708fa

Nicholls, M., Scaife, R., 2008. Palaeoenvironmental reconstruction from sediments at West Quay Road, Southampton. Journal of Wetland Archaeology 8, 91-119. https://doi.org/10.1179/jwa.2008.8.1.91

Orme, L.C., Reinhardt, L., Jones, R.T., Charman, D.J., Barkwith, A., Ellis, M.A., 2016. Aeolian sediment reconstructions from the Scottish Outer Hebrides: Late Holocene storminess and the role of the North Atlantic Oscillation. Quaternary Science Reviews 132, 15-25. https://doi.org/10.1016/j.quascirev.2015.10.045 
Pagani, M., Pedentchouk, N., Huber, M., Sluijs, A., Schouten, S., Brinkhuis, H., Sinninghe

1066 Damsté, J.S., Dickens, G.R., Backman, J., Clemens, S., Cronin, T., Eynaud, F., Gattacceca, 1067 J., Jakobsson, M., Jordan, R., Kaminski, M., King, J., Koc, N., Martinez, N.C., Mclnroy, D., 1068 Moore Jr, T.C., O'Regan, M., Onodera, J., Pälike, H., Rea, B., Rio, D., Sakamoto, T., Smith, 1069 D.C., St John, K.E.K., Suto, I., Suzuki, N., Takahashi, K., Watanabe, M., Yamamoto, M., 1070 Expedition, S., 2006. Arctic hydrology during global warming at the Palaeocene/Eocene 1071 thermal maximum. Nature 442, 671-675. 10.1038/nature05043

Parker, A.G., 2000. Biotic response to Late Quaternary global change - the pollen record: a case study from the Upper Thames Valley, England, in: Culver, S.J., Rawson, P. (Eds.), 1074 1075 Biotic Response to Global Change: the Last 145 Million Years. Cambridge: Cambridge University Press, 265-287.

Parker, A.G., Preston, G.W., 2014. Minchery Farm, Littlemore, Oxford: Geoarchaeology and 1077 Palaeoenvironments, Archaeology of East Oxford Report: Oxford University.

Parker, A.G., Robinson, M.A., 2003. Palaeoenvironmental investigations on the middle 1079 Thames at Dorney, UK, in: Howard, A.J., Macklin, M.G., Passmore, D.G. (Eds.), Alluvial 1080 Archaeology in Europe. Lisse: Swets and Zeitlinger, 43-60.

Pennington, W., Tutin, T., Bertie, D., 1977. The Late Devensian flora and vegetation of Britain [and discussion]. Philosophical Transactions of the Royal Society B: Biological Sciences 280, 247-271. https://doi.org/10.1098/rstb.1977.0109 scheme, Kent: archaeological survey. Stage 4b: report on pre-evaluation fieldwork. Archaeoscape Report for Mott MacDonald. 
Preece, R.C., Bridgland, D.R., 1998. Late Quaternary environmental change in north-west Europe: excavations at Holywell Coombe, South-East England Chapman \& Hall Ltd.

Preece, R.C., Bridgland, D.R., 1999. Holywell Coombe, Folkestone: A 13,000 year history of an English chalkland valley. Quaternary Science Reviews 18, 1075-1125. https://doi.org/10.1016/S0277-3791(98)00066-3

Proske, U., Wood, R., Fallon, S., Stevenson, J., 2015. Use of heavy liquid density separation to remove pyrite from sediment samples for radiocarbon dating. Quaternary Geochronology 25, 66-71. https://doi.org/10.1016/S0277-3791(98)00066-3

Racine, C.H., Dennis, J.G., Patterson, W.A., III, 1985. Tundra Fire Regimes in the Noatak River Watershed, Alaska: 1956-83. Arctic 38, 194-200. 10.2307/40510382

Radley, J., Tallis, J., Switsur, V., 1974. The excavation of three 'narrow blade' Mesolithic sites in the Southern Pennines, England. Proceedings of the Prehistoric Society 40, 1-19. https://doi.org/10.1017/S0079497X00011270

Rasmussen, S.O., Bigler, M., Blockley, S.P., Blunier, T., Buchardt, S.L., Clausen, H.B., Cvijanovic, I., Dahl-Jensen, D., Johnsen, S.J., Fischer, H., Gkinis, V., Guillevic, M., Hoek, W.Z., Lowe, J.J., Pedro, J.B., Popp, T., Seierstad, I.K., Steffensen, J.P., Svensson, A.M., Vallelonga, P., Vinther, B.M., Walker, M.J.C., Wheatley, J.J., Winstrup, M., 2014. A stratigraphic framework for abrupt climatic changes during the Last Glacial period based on three synchronized Greenland ice-core records: refining and extending the INTIMATE event stratigraphy. Quaternary Science Reviews 106, 14-28.

http://dx.doi.org/10.1016/j.quascirev.2014.09.007 
Rawat, Y., Everson, C., 2012. Ecological status and uses of juniper species in the cold desert environment of the Lahaul valley, North-Western Himalaya, India. Journal of Mountain Science 9, 676-686. https://doi.org/10.1007/s11629-012-2274-0

Razzhavin, V., 2012. Dwarf shrub heath in: Nutall, M. (Ed.), Encyclopedia of the Arctic. New York: Routledge, 515-516.

Reille, M., 1995. Pollen et spores d'Europe et d'Afrique du Nord: supplement 1. Marseille: Laboratoire de Botanique Historique et Palynologie

Reimer, P., Hoper, S., McDonald, J., Reimer, R., Svyatko, S., Thompson, M., 2015. The Queen's University, Belfast: laboratory protocols used for AMS radiocarbon dating at the ${ }^{14} \mathrm{CHRONO}$ Centre. Portsmouth: English Heritage Research Report.

Reimer, P.J., Bard, E., Bayliss, A., Beck, J.W., Blackwell, P.G., Bronk Ramsey, C., Buck, C.E., Cheng, H., Edwards, R.L., Friedrich, M., Grootes, P.M., Guilderson, T.P., Haflidason, H., Hajdas, I., Hatté, C., Heaton, T.J., Hoffmann, D.L., Hogg, A.G., Hughen, K.A., Kaiser, K.F., Kromer, B., Manning, S.W., Niu, M., Reimer, R.W., Richards, D.A., Scott, E.M., Southon, J.R., Staff, R.A., Turney, C.S.M., van der Plicht, J., 2013. IntCal13 and Marine13 radiocarbon age calibration curves $0-50,000$ years cal BP. Radiocarbon 55, 1869-1887. https://doi.org/10.2458/azu_js_rc.55.16947

Richardson, D.M., 2000. Ecology and Biogeography of Pinus Cambridge University Press.

Robinson, D., 1984. The estimation of charcoal content of sediments: a comparison of methods on peat sections from the Island of Arran. Circaea 2, 121-128. 
Rocha, A.V., Shaver, G.R., 2011. Postfire energy exchange in arctic tundra: the importance and climatic implications of burn severity. Global Change Biology 17, 2831-2841. 10.1111/j.1365-2486.2011.02441.x

Rousseau, D.-D., Preece, R., Limondin-Lozouet, N., 1998. British late glacial and Holocene climatic history reconstructed from land snail assemblages. Geology 26, 651-654. https://doi.org/10.1130/0091-7613(1998)026\%3C0651:BLGAHC\%3E2.3.CO;2

Sandford, K.S., 1965. Notes on the gravels of the Upper Thames flood plain between Lechlade and Dorchester. Proceedings of the Geologists' Association 76, 61-66. https://doi.org/10.1016/S0016-7878(65)80015-3

Scaife, R., 1980. Late-Devensian and Flandrian palaeoecological studies in the Isle of Wight. Kings College London: Department of Geography.

Scaife, R., 1982. Late-Devensian and Early Flandrian vegetation changes in Southern England, in: Bell, M., Limbrey, S. (Eds.), Archaeological Aspects of Woodland Ecology. Oxford: British Archaeological Reports, 57-74.

Scaife, R., 1987. The Late-Devensian and Flandrian vegetation of the Isle of Wight, in: Barber, K.E. (Ed.), Wessex and the Isle of Wight Field Guide. Cambridge: Quaternary Research Association, 156-180.

Scaife, R., 1995. Boreal and Sub-boreal chalk landscape: pollen evidence, in: Cleal, R., Walker, K., Montague, R. (Eds.), Stonehenge in its landscape: twentieth-century excavations English Heritage, 51-55. 
Scaife, R., 2000a. Chapter 9 Palynology and Palaeoenvironment, in: Needham, S.P. (Ed.),

1149 Runnymede Bridge Research Excavations Volume 1. The Passage of the Thames Holocene

1150 Environment and Settlement at Runnymede. London: The British Museum Press, 168-187.

1151 Scaife, R., 2000b. Pollen analysis at Farlington Marshes: A vegetation history of Langstone

1152 Harbour, in: Allen, M.J., Gardiner, J. (Eds.), Our changing coast: a survey of the intertidal

1153 archaeology of Langstone Harbour, Hampshire. York: Council for British Archaeology, 1711154175.

1155 Scaife, R., 2001. The prehistoric vegetation of Midhurst: a pollen study of the Common at 1156 New Pond, in: Magilton, J., Thomas, S. (Eds.), Midhurst. Chichester District Archaeology 1157 [series] 1. Chichester: Chichester District Council, 95-102.

1158 Scaife, R., 2004. Denham, Bucks (50692): A preliminary pollen analysis of the Early 1159 Holocene peat sequences. Wessex Archaeology Report.

1160 Scaife, R., Unpublished-a. Hampshire. The Southern Pollen Review, Historic England.

1161 Scaife, R., Unpublished-b. The Isle of Wight. The Southern Pollen Review, Historic England.

1162 Scaife, R., Unpublished-c. Kent. The Southern Pollen Review, Historic England.

1163 Schefuß, E., Kuhlmann, H., Mollenhauer, G., Prange, M., Pätzold, J., 2011. Forcing of wet 1164 phases in southeast Africa over the past 17,000 years. Nature 480, 509-512.

$1165 \quad 10.1038 /$ nature10685 
Scott, E., 2003. The third international radiocarbon intercomparison (TIRI) and the fourth international radiocarbon intercomparison (FIRI) 1990-2002: results, analyses, and conclusions. Radiocarbon 45, 135-408. https://doi.org/10.1017/S0033822200032677

Scott, E.M., Cook, G.T., Naysmith, P., 2010. The Fifth International Radiocarbon Intercomparison (VIRI): an assessment of laboratory performance in stage 3. Radiocarbon 52, 859-865. https://doi.org/10.1017/S003382220004594X

Seagrief, S.C., Godwin, H., 1960. Pollen diagrams from Southern England: Elstead, Surrey. New Phytologist 59, 84-91. https://doi.org/10.1111/j.1469-8137.1960.tb06205.x

Shotton, F.W., Blundell, D.J., Williams, R.G., 1970. Birmingham University radiocarbon dates IV. Radiocarbon 12, 389. https://doi.org/10.1017/S0033822200008158

Simmonds, M., 2017. Examining the relationship between environmental change and human activities at the dryland-wetland interface during the Late Upper Palaeolithic and Mesolithic in Southeast England. PhD. University of Reading: Department of Archaeology.

Simmonds, M., Hosfield, R., Branch, N.P., Black, S., 2019. From findspot to site: a spatial examination of the Mesolithic resource in Surrey. Surrey Archaeological Collections 102, 4369.

Simmons, I.G., Innes, J.B., 1996. Prehistoric Charcoal in Peat Profiles at North Gill, North Yorkshire Moors, England. Journal of Archaeological Science 23, 193-197. http://dx.doi.org/10.1006/jasc.1996.0017 
1185

Slota, P., Jull, A.T., Linick, T., Toolin, L., 1987. Preparation of small samples for ${ }^{14} \mathrm{C}$ accelerator targets by catalytic reduction of CO. Radiocarbon 29, 303-306. https://doi.org/10.1017/S0033822200056988

Stace, C., 2010. New flora of the British Isles, Third Edition ed. Cambridge: Cambridge University Press.

Stenhouse, M., Baxter, M., 1981. Carbon-14 dating reproducibility: evidence from routine dating of archaeological samples, Proceedings of the First International Symposium ${ }^{14} \mathrm{C}$ and Archaeology, Groningen, 1981, 147-161.

Stockmarr, J., 1971. Tablets with spores used in absolute pollen analysis. Pollen et Spores 13, 615-621.

Stuiver, M., Polach, H.A., 1977. Discussion; reporting of C-14 data. Radiocarbon 19, 355363. https://doi.org/10.1017/S0033822200003672

Tallantire, P.A., 2002. The Early-Holocene spread of hazel (Corylus avellana L.) in Europe north and west of the Alps: an ecological hypothesis. The Holocene 12, 81-96. https://doi.org/10.1191\%2F0959683602hl523rr

The Museum of London, 2000. The Archaeology of Greater London. London: MoLAS.

Thomas, C., Rackham, J., Barham, A.J., Branch, N., Glorgi, J., Goodburn, D., Lowe, J., Neal, V., Rackham, J., Smith, D., Thomas, C., Tyers, I., Wilkinson, K., Williamson, V., 1996. Bramcote Green, Bermondsey: a Bronze Age trackway and palaeo-environmental sequence. Proceedings of the Prehistoric Society 62, 221-253. https://doi.org/10.1017/S0079497X00002796 
Thorley, A., 1981. Pollen analytical evidence relating to the vegetation history of the chalk.

1207 Journal of Biogeography 8, 93-106. DOI: 10.2307/2844552

Troels-Smith, J., 1955. Karakterisering af lose jordater (characterisation of unconsolidated sediments). Denmarks Geologiske Undersogelse Series IV/3, 73.

Vandeputte, K., Moens, L., Dams, R., 1996. Improved sealed-tube combustion of organic samples to $\mathrm{CO} 2$ for stable carbon isotope analysis, radiocarbon dating and percent carbon determinations. Analytical Letters 29, 2761-2773. https://doi.org/10.1080/00032719608002279

1214 Verbruggen, C., 1979. Vegetation and palaeoecological history of the Late Glacial period in sandy Flanders (Belgium). Acta Universitatis Oulensis, Series A, Geologica 82, 231-234. https://doi.org/10.1007/978-94-011-3592-4_36

1217 Walker, M., Bohncke, S., Coope, G., O'Connell, M., Usinger, H., Verbruggen, C., 1994. The 1218 Devensian/Weichselian Late-Glacial in northwest Europe (Ireland, Britain, North Belgium, 1219 The Netherlands, Northwest Germany). Journal of Quaternary Science 9, 109-118. https://doi.org/10.1002/jqs.3390090204

1221 Walker, M.J.C., Berkelhammer, M., Björck, S., Cwynar, L.C., Fisher, D.A., Long, A.J., Lowe, 1222 J.J., Newnham, R.M., Rasmussen, S.O., Weiss, H., 2012. Formal subdivision of the 1223 Holocene series/epoch: a discussion paper by a working group of INTIMATE (integration of 1224 ice-core, marine and terrestrial records) and the Subcommission on Quaternary Stratigraphy 1225 (International Commission on Stratigraphy). Journal of Quaternary Science 27, 649-659. https://doi.org/10.1002/jqs.2565 
Walker, M.J.C., Coope, G.R., Sheldrick, C., Turney, C.S.M., Lowe, J.J., Blockley, S.P.E., Harkness, D.D., 2003. Devensian Lateglacial environmental changes in Britain: a multi-proxy environmental record from Llanilid, South Wales, UK. Quaternary Science Reviews 22, 475520. https://doi.org/10.1016/S0277-3791(02)00247-0

Waller, M., Kirby, J., 2002. Late Pleistocene/Early Holocene environmental change in the Romney Marsh region: New evidence from Tilling Green, Rye, in: Long, A., Hipkin, S., Clarke, H. (Eds.), Romney Marsh: Coastal and Landscape Change through the Ages OUSA Monograph, 22-39.

Waller, M., Long, A., 2010. The Holocene coastal deposits of Sussex: a re-evaluation, in: Waller, M., Edwards, E., Barber, L. (Eds.), Romney Marsh: Persistence and Change in a Coastal Lowland Romney Marsh Research Trust, 1-21.

Waller, M.P., 1993. Flandrian vegetational history of south-eastern England. Pollen data from Panel Bridge, East Sussex. New Phytologist 124, 345-369. https://doi.org/10.1111/j.1469-8137.1993.tb03825.x

Waller, M.P., Hamilton, S., 2000. Vegetation history of the English chalklands: a midHolocene pollen sequence from the Caburn. Journal of Quaternary Science 15, 253-272. https://doi.org/10.1002/(SICI)1099-1417(200003)15:3\%3C253::AID-JQS481\%3E3.0.CO;2-8

Waller, M.P., Long, A.J., Long, D., Innes, J.B., 1999. Patterns and processes in the development of coastal mire vegetation: Multi-site investigations from Walland Marsh, Southeast England. Quaternary Science Reviews 18, 1419-1444. https://doi.org/10.1016/S0277-3791(98)00072-9 
Waller, M.P., Marlow, A.D., 1994. Flandrian vegetational history of south-eastern England. Stratigraphy of the Brede valley and pollen data from Brede Bridge. New Phytologist 126, 369-392. https://doi.org/10.1111/j.1469-8137.1994.tb03956.x

Ward, G.K., Wilson, S.R., 1978. Procedures for comparing and combining radiocarbon age determinations: a critique. Archaeometry 20, 19-31. https://doi.org/10.1111/j.14754754.1978.tb00208.x

Wein, R.W., 1976. Frequency and Characteristics of Arctic Tundra Fires. Arctic 29, 213-222. $10.2307 / 40508760$

Wessex Archaeology, 2006. Units 300/305, 310/315/320/325 and 400. Riverside Way, Uxbridge, London Borough of Hillingdon. Archaeological Evaluation Report, Wessex Archaeology.

Whittington, G., Buckland, P., Edwards, K.J., Greenwood, M., Hall, A.M., Robinson, M., 2003. Multiproxy Devensian Late-glacial and Holocene environmental records at an Atlantic coastal site in Shetland. Journal of Quaternary Science 18, 151-168. https://doi.org/10.1002/jqs.746

Whittington, G., Edwards, K.J., Zanchetta, G., Keen, D.H., Bunting, M.J., Fallick, A.E., Bryant, C.L., 2015. Lateglacial and early Holocene climates of the Atlantic margins of Europe: Stable isotope, mollusc and pollen records from Orkney, Scotland. Quaternary Science Reviews 122, 112-130. https://doi.org/10.1016/j.quascirev.2015.05.026

Wilkinson, K.N., Scaife, R.G., Sidell, E.J., 2000. Environmental and sea-level changes in London from 10500 BP to the present: a case study from Silvertown. Proceedings of the Geologists' Association 111, 41-54. https://doi.org/10.1016/S0016-7878(00)80035-8 
1270 Young, D.S., Green, C.P., Batchelor, C.R., Austin, P., Elias, S.A., Athersuch, J., Lincoln, P., 1271 In Press. Macrofossil evidence of alder (Alnus sp.) in Britain early in the Late Glacial

1272 Interstadial: Implications for the northern cryptic refugia debate. Journal of Quaternary 1273 Science.

1274 